Article

\title{
Gendered Strategies between Democratization and Democratic Reversal: The Curious Case of Turkey
}

\author{
Hürcan Aslı Aksoy \\ Institute for Political Science, University of Erlangen-Nürnberg, 91054 Erlangen, Germany; E-Mail: huercan.asli.aksoy@fau.de
}

Submitted: 14 February 2018 | Accepted: 25 June 2018 | Published: 14 September 2018

\begin{abstract}
The processes of democratization or democratic reversal have serious implications for gender equality regimes. Although the gender and transition literature has extensively examined the relation between democratization and gender, it only recently began to question how the changing dynamics of democratic reversal influence gender politics and policies. While women's participation and representation in the formal arena of politics has been the primary object of theoretical discussions, the research rediscovers the power of the informal arena. To find tentative answers to the newly developing research agenda, this article employs the case of Turkey. To this end, the article examines the gendered strategies of four groups of organized women (feminist, Kurdish, Islamist, and Kemalist women's organizations) engaged in strengthening women's rights and gender equality. It first questions how, and to what extent, organized women engendered democratization process and then sheds lights on the shift in their strategies to respond to the increasingly authoritarian and conservative Islamist political agenda of the ruling Justice and Development Party. Drawing on empirical findings, the article aims to inform the theoretical debates on the analytical relation between democratic reversals and gender rights regimes.
\end{abstract}

\section{Keywords}

democratic reversal; democratization; gender politics; Justice and Development Party; organized women; Turkey

\section{Issue}

This article is part of the issue "The Feminist Project under Threat in Europe", edited by Mieke Verloo (Radboud University, The Netherlands) and David Paternotte (Université Libre de Bruxelles, Belgium).

(C) 2018 by the author; licensee Cogitatio (Lisbon, Portugal). This article is licensed under a Creative Commons Attribution 4.0 International License (CC BY).

\section{Introduction}

On 5 June 2016, at the opening of the new building of the Kadın ve Demokrasi Derneği (KADEM) [Women and Democracy Association], Turkish President Recep Tayyip Erdoğan asserted that "a woman who rejects motherhood, who refrains from being around the househowever successful in her work life-is deficient, and is incomplete" (The Guardian, 2016). He further recommended that women should have at least three children, which he frequently mentions in his public speeches. These statements were one of the latest in a series of controversial remarks that impose conservative family values and norms on women. Erdoğan repeatedly declared that he does not believe in equality of women and men because they are biologically different and have differ- ent societal roles (The Guardian, 2014). Women's rights advocates have claimed that Erdoğan's remarks create a climate in which intimidation, discrimination, and abuse of women became normalized. The growing social conservatism, which is not unique to Turkey, is utilized to legitimize the reconfiguration of the political rule under the Adalet ve Kalkınma Partisi (AKP) [Justice and Development Party].

The ruling AKP, which came to power in 2002, pursued a series of political and economic reforms. After a period of a democratic progress, the AKP began "to cement its own hold on power" (Müftüler-Baç \& Keyman, 2012 , p. 86) and to restrict the leeway for the democratic opposition, civil society, and the media. Turkey's imperfect democracy turned into a form of "competitive authoritarianism"1 (Esen \& Gumuscu, 2016; Öniş, 2013). With

${ }^{1}$ Levitsky and Way state that in competitive authoritarian regimes formal democratic institutions (e.g., free and fair elections, political rights and civil liberties) are viewed as the principal means of obtaining and exercising political authority. However, incumbents violate those rules so frequently that it creates an "uneven playing field" between government and opposition (2002, pp. 52-53). 
the rise of authoritarianism, patriarchal notions and conservative family values have become more salient in the AKP's political discourse on women (Acar \& Altunok, 2013; Altunok, 2016; Güneş-Ayata \& Doğangün, 2017; Kandiyoti, 2015, 2016). The patriarchal control of gender relations leads to a perpetual conflict between the government and women's organizations struggling for women's equal rights. Thus, the article aims to examine the strategies of women's organizations in the process of democratization and democratic reversal under the conservative political agenda of the AKP. Drawing on the arguments of "democratization from below", the article argues that organized women play a substantial role in negotiating gender issues and responding to negative changes in gender policies in a political environment, where anti-democratic and anti-gender sentiments are on the rise.

The article examines the strategies of organized women in Turkey defending gender equality. Although the concept of gender equality can have multiple meanings in different political contexts (cf. Verloo, 2007), here it refers to formal equality, in which all women and men have similar opportunities to participate in politics, economy, and society. By employing a qualitative analysis, the article aims to shed light on the role of organized women in defying the conservative and authoritarian gender discourse and practices of the AKP. The findings on Turkey may provide valuable insights into the newly emerging field within the gender and politics scholarship dealing with backsliding in gender equality in the context of dedemocratization and democratic reversal.

\section{A Gendered Approach to Democratization and Democratic Reversal}

The concept of democratization encompasses two discussions: 1) how to define democracy, and 2) what are the favoring and disfavoring conditions of a democratization process. In line with the mainstream democratization literature, the article employs a mid-range definition of democracy-a procedural understanding of democracy - that focuses on the institutions and rules of democracy. Although the conducive factors that facilitate democratization and the consolidation of democracy are still disputed in democratization studies, the main consensus is that the democratization process is not an irreversible condition. In other words, democracies can always become weaker or stronger (Diamond, 1997; Linz \& Stepan, 1997). Thus, the literature deals with both directions within the process of democratization; i.e., transition to democracy and democratic reversal.

In recent years, countries around the globe experienced democratic decline, and even suffered democratic reversal. Since citizens think that governments do not substantially represent their interests, they are tempted either to support populist leaders with weak democratic credentials (Ottoway, 2000), or to mobilize for a better democracy (Diamond \& Plattner, 2015). As Freedom House claims in its 2017 report, "the dual threat" to democracy, i.e., rising populism and authoritarianism, challenges the progress made in political rights and civil liberties globally. This anti-democratic wave has far-reaching consequences for women's rights and gender equality, too. We already witness a strengthening of anti-feminist politics and anti-gender movements, growing online violence against women in politics, and the perennial problem of domestic violence against women (see introduction of this issue). While the "malestream democratization literature" (Waylen, 2007) seeks to understand reasons behind democratic reversals, it completely ignores the gender perspective of the phenomenon. Gender and politics scholars thus began to investigate to what extent these anti-democratic and anti-gender developments represent a threat to the achievements in gender equality regimes and to gender relations (e.g. this issue). But further research is needed to examine how exactly democratic reversal affects women's rights actors both in- and outside of formal politics and how they should resist and counteract de-democratization processes.

To investigate the negative developments in gender policies, gender and politics scholars studying more gender equal societies of the West focus mostly on the formal arena of politics (executive, legislative, and judiciary bodies) in shaping the nature of institutions and processes. Waylen, for instance, suggests changing the institutions of democracy "to promulgate democracies with enhanced levels of participation, representation and legitimacy" (2015, p. 498). To this end, scholars suggest introducing gendered institutional mechanisms such as gender quotas, or to strengthen state's women's agencies in order to increase women's participation and representation and thereby hinder the crises in democracies (e.g., Krook \& Messing-Mathie, 2013; Waylen, 2015). Nevertheless, how to resist reversal in democracies and how to prevent backsliding in gender policies and laws remain to be resolved in the literature. Since trust in democratic institutions is declining, but public interest in "doing politics" has been rising (Diamond \& Plattner, 2015), it is time for scholars to reconsider and re-examine the informal arena of politics, especially civil society, which is "an area of contesting projects" (Walby, 2011, p. 6). The collective, autonomous, and voluntaristic character of civil society provides women and men with the opportunity to voice and mobilize for their gendered demands. In line with gender and politics scholars studying developing countries with less gender equality regimes (Latin America, Sub-Saharan Africa, Southeast Asia, and the Middle East), we can argue that within the civil societal space, organized women not only have the chance to monitor state's gender policies but also to resist negative changes and backsliding in policies and laws. Although a great deal of the literature on social movements examines women's organizing in civil society, its main interest remains the aims, internal characteristics, and framing of their demands (Waylen, 2007, p. 51). This is not sufficient to examine the interaction of organized women 
with state institutions and the political context. Thus, a thorough gendered examination of democratization and democratic reversal needs to consider women's agency in the informal arena of politics, without ignoring the interaction with the formal arena. To this end, the article pays particular attention to women's civil society organizations (CSOs) and their interaction with state institutions in formulating gender policies and in rejecting antifeminist policies and regulations that are detrimental to gender equality.

In this article, I will focus on four groups of women's organizations that reflect the dominant political cleavages in Turkey: feminist, Kurdish, Islamist, and Kemalist women's CSOs. Most of the scholarly literature on women's organizing in Turkey refer to these four groups and examine them, albeit to different extents (e.g., Arat, 2008; Bora \& Günal, 2007; Coşar \& Onbaşi, 2008; Diner \& Toktaş, 2010; Marshall, 2009). For each group, I selected three organizations that are each highly influential and representative within their groups, and that are not dependent on political parties. ${ }^{2}$ The study deployed a qualitative analysis and collected the empirical data mainly from the primary sources. First, I conducted twenty semistructured, in-depth interviews with the executive members of the selected women's CSOs and feminist academics during research trips between 2010 and 2012 . Second, in October 2016, I met academics and women's rights activists from different women's groups in a research workshop organized by University of Bremen. There, I had the opportunity to discuss how women's groups resist the recent conservative gender politics of the ruling AKP. Third, to supplement the data, I reviewed publications, public statements, and interviews in newspapers and social media accounts of the selected women's CSOs. Fourth, the study profited from the grey literature, i.e., the surveys and reports of the Ministry of Family and Social Policies and of national and international research institutes to identify state's projects and policies related to gender issues. In doing so, I applied process tracing, and textual analysis of these data. The evidences obtained from the state's reports were compared with the reports conducted by autonomous nongovernmental organizations (NGOs) to verify or falsify the findings. Secondary sources, e.g., the journal articles on gender issues and gender politics in Turkey, provided me with further data. In the following, first, the trajectory of Turkish democracy will be delineated. Thereafter, organized women's strategies will be examined in the context of democratization and democratic reversal.

\section{Women's Organizing, Democratization, and Democratic Reversal in Turkey}

In democratization studies, Turkey constitutes an unusual case. Although the transition to multi-party politics had been accomplished seven decades ago, Turkey failed to consolidate its democracy based on a pluralistic and inclusive political order (Öniş, 2013). During these seven decades, Turkish democracy was punctuated by numerous breakdowns and restorations, which were caused by the military's direct or indirect interventions (1960, 1971, 1980, and 1997). In this military-dominated political space, civil society was considered a way of resisting the strong state and of incubating pluralistic society in Turkey. As the literature on women's movements in Turkey acknowledges, organized feminist women were the first group within civil society that had the courage to challenge the military dominance and voice their demands for more freedom, democracy, and gender equality (e.g., Arat, 2008; Bora \& Günal, 2007; Diner \& Toktaş, 2010; Marshall, 2009). ${ }^{3}$ From the mid-1990s on, the public visibility of feminists encouraged women from other oppositional movements to mobilize around women's issues, especially from the Islamist and Kurdish movements. Feminist organizing was important in the development of diverse women's movements within the illiberal political space, but tensions existed among different organized women's groups around issues of ethnicity, religion, class, and the meaning of feminism (Arat, 2008; Diner \& Toktaş, 2010). Despite the ideological fragmentation, women's organizations proliferated and created a range of mobilizing structures to challenge patriarchal structures in society and politics. With the rise of the Islamist AKP to power in 2002, Turkey entered another phase in its political development. In its first term (2002-2007), the AKP, in line with Turkey's prospect of being a European Union (EU) member, successfully initiated democratic reforms to strengthen political rights and civil liberties (Aydin \& Keyman, 2004; Öniş, 2013). In this period, civil society-including organized womenwas highly active in pushing for the consolidation of democracy in Turkey. After this remarkable democratic progress, the AKP decelerated the democratization process in its second term (2007-2011). The AKP leadership began to emphasize an economically strong Turkey with a rather minimalist understanding of democratic rights and institutions (Öniş, 2013, p. 114). Thanks to the 2010 constitutional referendum that led to a restructuring of the judiciary and increased civilian oversight of the military, the AKP could further consolidate its own power at the expense of the legislative and the judiciary power (Esen \& Gumuscu, 2016). In its third term (2011-2015), especially after the 2013 summer protests (known also as Gezi protests) directed against authoritarian rule of the AKP and the coup attempt in July 2016, the government increased political pressure on business, the opposition, and civil society and limited the leeway for independent media. The latest political developments clearly point to a democratic reversal. These developments include: mass arrests of opposition members and journal-

\footnotetext{
2 I do not name the selected women's CSOs due to the limited space; see further (Aksoy, 2017).

${ }^{3}$ It is claimed that in authoritarian regimes, where the political arena is substantially constrained, the identification of women as "apolitical" and their activities as "not being political enough" allow women to organize their activities in civil society (Waylen, 2007, p. 56).
} 
ists, purges in public institutions, constraints on freedom of assembly and association, palpable deficiencies in the rule of law, and the disregard of the diverse segments of civil society, except for the government supported Islamist NGOs (Freedom House, 2017). With the constitutional referendum in April 2017 and the re-election of Recep Tayyip Erdoğan to the presidency in June 2018, which transformed the country from a parliamentary into a presidential system, Turkey evolved from electoral democracy to "competitive authoritarian regime" (Esen \& Gumuscu, 2016). Against this political background, organized women search for strategies to deal with the increasingly authoritarian and ultra-conservative Islamist politics of the AKP.

\section{Gendered Strategies in Democratization and Democratic Reversal in Turkey}

During the first two terms of the AKP (2002-2007 and 2007-2011), positive changes were witnessed in women's rights and gender equality policies (Acar \& Altunok, 2013; Aksoy, 2017; Güneş-Ayata \& Doğangün, 2017; Kandiyoti, 2016). The AKP introduced new laws, regulations, and mechanisms to prevent violence and discrimination against women and to strengthen women's rights to attain gender equality: The Labor Law reform (2003); the Penal Code reform (2004); the reform of Article 14 of the Municipality Law (2005) forcing municipalities with more than 50.000 inhabitants to establish women's shelters. With the introduction of a clause (Art. 10) in the Turkish Constitution (2004), the state became obligated to take all necessary measures to achieve gender equality. In 2007 and 2012, Kadının Statüsü Genel Müdürlüğü (KSGM) [The General Directorate on the Status of Women], the state body responsible for women's affairs, launched action plans for combating violence against women.

These gender-sensitive laws and policies were introduced not only due to the EU accession processes but also thanks to the involvement and domestic pressure of women's CSOs in policymaking processes (Acar \& Altunok, 2013; Kandiyoti, 2015). Women's CSOs participated in most phases of policymaking: in agenda setting, in decision-making, implementation, monitoring, and even in policy evaluation. Clearly, during the first two terms of the AKP, women's CSOs were successful in translating their gendered claims into concrete laws and policies strengthening women rights. However, beginning with the third term of the AKP (2011), there has been a remarkable shift in party's approach to gender policies. The AKP began to strongly emphasize women's designated roles as "mothers" and to promote pro-natal policies (Altunok, 2016; Güneş-Ayata \& Doğangün, 2017; Kandiyoti, 2016). In such an increasing patriarchal domination of the AKP and its authoritarian grip on power, Turkey began to witness the dismantling of existing progressive gender policies and the exclusion of autonomous women's CSOs from policymaking processes. Occasion- ally, Erdoğan and the other AKP leaders attempt to publicly discredit feminist activists. Instead, the AKP incorporates government-organized NGOs (GONGOs), focusing on women's issues, in policymaking processes to support its conservative public policies (Aksoy, 2015; Kandiyoti, 2015). The government sponsors these GONGOs to represent Turkey in international women's forums. This helps the AKP to control civil society effectively. Against this background, autonomous women's CSOs seek alternative ways to pursue their activities. How do organized women deal with the enforced conservative gender policies that push women to accept traditionally designed gender roles? What strategies do they develop to resist the AKP's repressive politics? In the following section, I focus on the strategies of the aforementioned four groups of women's CSOs before and after 2011 to highlight the shift in AKP's gender politics that accompanied its authoritarian turn.

\subsection{Feminist Women's CSOs}

Like the second wave feminists of the 1960s and 1970s in the West, Turkish feminists-organized in the 1980s - focused on issues such as gendered inequalities, domestic violence, sexual harassment, women's sexuality, and women's reproductive rights (Arat, 2008; Bora \& Günal, 2007; Coşar \& Onbaşi, 2008). Thanks to their institutionalization in organizations in the 1990s, feminist women were able to approach and interact with state institutions responsible for gender policies more easily. They pressured the governments for the removal of discriminatory and women-unfriendly formulations in laws (Diner \& Toktaş, 2010). Moreover, using their increased cooperation with the international women's networks such as the United Nations Women and the Convention on the Elimination of All Forms of Discrimination against Women (CEDAW) Committee, they increased their bargaining power with state institutions to improve women's rights. However, in the 1990s, there was not much alliance and coalition-building between feminist CSOs and other organized women's groups.

\subsubsection{Engendering the Democratization before 2011}

In the beginning of the 2000s, the Turkish laws relating to women rights had to be adapted to EU law. Feminist CSOs thus gained an important opportunity for advancing women's rights. They were highly active and influential in the amendment processes of the Civil and the Penal Code (Arat, 2008; Kandiyoti, 2015; Marshall, 2009). While the new Civil Code (2002) guaranteed equality between men and women within the family unit, the Penal Code revision was a major step in criminalizing violence against women. However, policymakers and feminist CSOs ran into several controversies. In 2004, the then prime minister Recep Tayyip Erdoğan made a last-minute interference in the Penal Code reform process pushing for the criminalization of adultery. Femi- 
nist CSOs used the following strategies to counteract this proposal: 1) mobilizing women through demonstration and a nation-wide petition, 2) reaching out for support from women's international networks and the EU institutions, and 3) attracting the Turkish media's attention. In response to the domestic and international pressures, the AKP retracted the proposal on criminalizing adultery. Reforming the Civil and Penal Code was not only a major step in strengthening women's rights, but also enhanced women's substantive representation; i.e., the expression of women's interests in policies and institutions.

In 2004, feminist CSOs lobbied key parliamentarians to have the gender equality clause enshrined in the Turkish Constitution. The article in question (Article 10) stipulates: "women and men have equal rights. The State is responsible for taking all measures to realize gender equality" (Amend 7.5.2004-5170, Clause 1). Another encounter was in 2011, when feminists pushed for the revision of the existing Law on the Protection of the Family (No 4320). The Ministry of Family and Social Policies included representatives of Siddete Son Platformu [Stop Violence Platform]-consisting of 241 women's organizations-in the policymaking process. Feminist CSOs formed nationwide networks, established web-based blogs to inform the Turkish public on the new Protection Law (No 6284) and continued to lobby parliamentarians sympathetic to feminist demands. One of my interviewees, who was active in the policymaking process, stated that:

During the process of amending the Protection Law, we have been screening the draft proposal and addressing the problematic formulations such as excluding "non-married women" from the protection law. The Minister (for Family and Social Policies) Fatma Şahin and her officials were mostly responsive to our demands, but they were feeling the pressure of the conservative basis of the party (AKP). ${ }^{4}$

The new Law to Protect Family and Prevent Violence against Women (No 6284), which was amended on 8 March 2012, increased the sentences for violence against women and developed state-led central mechanisms to prevent violence against women and children. In addition to organizing issue-specific campaigns and lobbying activities for achieving gender equality, feminist CSOs continued their activities to raise women's awareness of their legal rights. In addition, they prepared shadow reports, which are produced by women's CSOs in the countries that signed the CEDAW agreement, to highlight discriminatory provisions in the legal framework and call for immediate actions. This is a way to create external pressure on the ruling AKP. In this period, feminist CSOs played an important role in policymaking processes pertaining to women's rights.

\subsubsection{In the Shadow of Authoritarianism after 2011}

After 2011, when the process of democratic reversal began, organized feminists pointed out the connections between the rising authoritarianism and "religio-conservative" (Güneş-Ayata \& Doğangün, 2017) practices of the AKP. Feminist activists and scholars alike stressed that Erdoğan's recurrent statements on women's roles as "mothers" constitute the central axis of the party's populist and authoritarian rhetoric and politics (Acar \& Altunok, 2013; Güneş-Ayata \& Doğangün, 2017; Kandiyoti, 2016). To resist the AKP's conservative policy proposals, feminist CSOs began to form large informal women's platforms bringing together many organizations from different women's groups. Kadın Cinayetlerini Durduracağız Platformu (We Will Stop Femicide Platform), for instance, can exert considerable influence on the public agenda regarding gender-based violence. This Platform helps to not only attract the public's attention, but it also pushes judges and state prosecutors to enforce laws correctly by following the court cases pertaining to violence against women. Different from the short-lived and issue-oriented national women's coalitions they built before 2011, when the AKP was responsive to the demands of women's rights advocates, feminist CSOs now prefer to build large and informal women's platforms to prevent backsliding in gender policies during the democratic reversal.

In 2013, for instance, Erdoğan commenced a public debate on abortion, although women have legally been able to have abortions since 1983. Erdoğan stressed that abortion is not an issue of women's bodily rights, but rather it is the right of the embryo to be born. Similar to women's protests in Poland, feminist CSOs immediately initiated a campaign called "Abortion is a Right" through social media. They reached an international audience and organized sit-in demonstrations in different cities to oppose the newly planned laws on birth control and abortion (Letsch, 2013). Feminist, Kurdish, and Kemalist women's groups, along with members of the Turkish Doctors Union, criticized the AKP's attempt to outlaw abortion through several press releases. The AKP thus withdrew its draft proposal due to the domestic and international reactions; however, public hospitals have been rejecting women's request for abortions with de facto state decrees (Yüncüler, 2014).

One of the latest attacks of the conservative AKP politicians was the law proposal that has been labelled the "rape law" (November 2016). The law proposal meant to grant amnesty to persons charged with child sexual assault, if they marry their victims, and the act was committed "without force, threat, trick or any other restriction of consent" (Cupolo, 2016). This proposal caused a public outcry and triggered nationwide protests and the Twitter campaign (\#tecavüz-rape) of women's platforms, in which feminist CSOs were highly visible. The AKP officials rejected the criticism and claimed that this

\footnotetext{
${ }^{4}$ Personal interview, February 2012, Istanbul.
} 
law aimed at helping couples who fell afoul of the law "because they had underage, but consensual sex and wanted to marry" (Tremblay, 2016). The parliamentary opposition criticized the bill and rejected it in the second round of voting. Thus, the AKP government was forced to withdraw the bill.

Put together, to resist the AKP's increasing hostility towards feminist demands, organized feminists, like their counterparts around the world (e.g. women's marches), prefer to go onto the streets to protest and make their claims visible. Similar to feminists in Latin America (Chile, Argentina and Brazil under military authoritarian regimes), they employ a two-level-strategy. First, on the national level, they conduct their advocacy efforts through large women's coalitions that are not shortterm and issue-specific as it was in the 1990s and the 2000s. Second, on the international level, the feminist CSOs continuously inform international women's networks on backsliding in gender policies to create external pressure on the AKP. They extensively use social media to mobilize women for defending women's rights, like the virally spread \#MeToo campaign. ${ }^{5}$ Feminist groups shifted their pro-active strategy to influence gender issues into a defensive one. As one feminist activist claimed in our interview:

We [feminists] used to reach the parliamentary commissions and parliamentarians easily and could influence decision-making processes in advancing women's rights. But nowadays, Erdoğan and the AKP politicians ignore our demands, marginalize and humiliate us in their public speeches. Erdoğan repeats his religious and sexist views on women and demands from his people [ministers] legal changes accordingly. In this atmosphere, our struggle only focuses on preventing the regressive changes, rather than advancing them. ${ }^{6}$

\subsection{Islamist Women's CSOs}

Islamist women's activism emerged with the aim of expanding the secular public space for women with headscarves. Islamist women activists argued that the headscarf ban, which prohibited wearing headscarf in public institutions, is a violation of basic rights of women, as it hinders women's participation in the educational, professional, and political life (Ozcetin, 2009, p. 113). To voice their demands for participation and inclusion in the public sphere, without being pushed back by Islamist men, Islamist women formed their own CSOs (Aksoy, 2015, p. 154). They contested not only the Turkish state's understanding of secularism, which strictly controlled religion, but also the patriarchal hierarchies within the
Islamist movement (Arat, 2008; Diner \& Toktaş, 2010; Ozcetin, 2009). Their main concern was fighting against the secularist state that discriminated against religious women. Due to the ideological polarization in Turkey, the Islamist women CSOs could not cooperate with other women's groups on gender issues until the 2000s.

\subsubsection{Engendering the Democratization before 2011}

With the rise of the AKP to power in 2002 and the positive atmosphere of the EU accession process, Islamist women's CSOs began to cooperate with some feminist and Kurdish women's CSOs to improve women's rights. ${ }^{7}$ The first instance of cooperation occurred when organized Islamist women participated in the reform process of the Penal Code. ${ }^{8}$ Islamist women's CSOs were especially influential in lobbying AKP politicians by conveying religious women's views, who were perceived as the party's own clientele. In 2011, during the reform process of the Protection Law (No 6284), Islamist women's CSOs consulted bureaucrats about violence against women. In their advocacy and lobbying efforts, they employed two strategies: 1) cooperating with state bodies responsible for gender policies, and 2) networking with feminist and Kurdish women's groups. Within the framework of the government's first National Action Plan (20072010) to combat violence against women, organized Islamist women trained public officials in gender equality. As they engaged with other women's groups in policymaking, they became active agents in the democratization process under AKP rule.

\subsubsection{In the Shadow of Authoritarianism after 2011}

From the summer protests of 2013 onward, some Islamist women activists acknowledged the fact that the AKP ignores their demands, although both stem from the Islamist movement. As the AKP strove to build a conservative society acting according to its interpretation of religious tradition, it began to build and finance its own women's CSOs, mostly run by the female relatives of the AKP leadership. ${ }^{9}$ These GONGOs promote pro-family and anti-egalitarian rhetoric (Altunok, 2016, p. 142), and do not facilitate a gender perspective. Against this background, the coalition with other women's CSOs became indispensable for critical Islamist women's groups. The most prominent example of cooperation between Islamist and secular women's groups was during the abortion debate in 2013. When organized feminists initiated a petition campaign on keeping abortion legal, a few organized Islamist women supported them. In their public statements, these Islamist women underscored women's bodily rights, which include, inter alia, wear-

\footnotetext{
${ }^{5}$ The scholarly discussion on the social media's influence and effectiveness on social movements is a newly developing research field.

${ }^{6}$ Personal talk, October 2016, Bremen.

${ }^{7}$ Admittedly, the Islamist women's CSOs I interviewed represent only one segment of organized Islamist women. Among organized Islamist women, there are many orthodox groups that might refrain from cooperating with other women's groups.

8 Personal interview, November 2010, Istanbul.

${ }^{9}$ The best example is the Women and Democracy Association (KADEM). Erdoğan's daughter is in the executive committee of the association.
} 
ing a headscarf, and argued that the state may not interfere in women's bodily rights. Since Islamist women suffered under the secularist state's intervention into their physical appearance because of their headscarves, they did not hesitate to criticize the state's interference in women's bodily rights (Aksoy, 2015, p. 165). Besides the national networking with other women's CSOs, Islamist women's CSOs also expanded their networks on the international level, especially with women's groups from Muslim countries. In light of rising Islamophobia, they discuss the living conditions of Muslim women around the world.

Lately, organized feminists complained about the silence of Islamist women's CSOs about rising authoritarian politics of the AKP. ${ }^{10}$ Turam additionally argues that Islamist women under AKP rule have not mobilized to defend their rights (2008, p. 486). Instead of confronting the AKP and its patriarchal approach to gender politics together with other women's groups, Islamist women's CSOs began to engage in "less political subjects" such as women's participation in work force. Although these issues are quite important for achieving gender equality, organized feminists claim that they need the support of Islamist women to resist backsliding in gender equality policies. Only one of the Islamist women's CSOs I interviewed still participate in organized women's struggles to defy AKP's conservative discourse and policies. The other two CSOs are co-opted by the AKP, and they have already become instrumentalized for government policies to protect and elevate family values, traditions, and morality.

\subsection{Kurdish Women's CSOs}

The experiences during the Kurdish-Turkish conflict and the propinquity to the Kurdish national movement through Partiya Karkerên Kurdistan's (PKK) [Kurdistan Workers Party] ethnic propaganda resulted in increased political awareness among Kurdish women (Gökalp, 2010, p. 562). Although "Kurdishness" was the defining element of the Kurdish women's activism, organized Kurdish women raised their concerns on gender issues such as woman's sexuality, domestic violence, incest, rape, and the understanding of shame and honor both in Turkish and Kurdish society (cf. Diner \& Toktaş, 2010). They claimed that Turkish feminist activism ignored the ethnicity dimension of women's subordination and failed to realize that Kurdish women suffer a double-discrimination, both an ethnic- and a gender-based discrimination (Aksoy, 2017). To voice their ethnicity and gender-based demands, Kurdish feminists formed their own women's organizations. Gökalp argues that due to the ethnonationalist tendencies and radical politicization among Kurdish women, organized Kurdish women failed to garner recognition as democratic actors in Turkish public opinion in the 1990s (2010, pp. 566-567).

\subsubsection{Engendering the Democratization before 2011}

In the early 2000s, Kurdish women's CSOs could not participate in the reform processes of the Civil and Penal Code, as they were perceived as "separatists" by the nationalist, religious, and secularist members of the Turkish parliament. However, they were engaged in studying the causes of violence against women, especially "honor killings" in the Kurdish populated regions. Kurdish women's CSOs pointed out prevailing state violence in Kurds' daily life that perpetually produced and legitimized a "culture of violence". This, in turn, made domestic abuse a common practice in Kurdish homes. Thanks to their links to local municipalities under the control of the Kurdish parties, they successfully disseminated information on women's legal rights both in the Kurdish and Turkish language. With the election of Kurdish politicians into the Turkish parliament in 2007, they became active agents in policymaking processes. They developed the following strategies: 1) lobbying parliamentarians for the classification of honor killings as an "aggravated circumstance", 2) informing international women's platforms on the laws regarding honor killings, and 3) keeping the public's attention within the Kurdish region on the issue of violence against women. Their active engagement together with other organized women's groups played a substantial role in the final revision of the Protection Law (No 6284).

\subsubsection{In the Shadow of Authoritarianism after 2011}

With the authoritarian turn in Turkish politics, the AKP began to closely monitor the activities of CSOs deemed to be "antagonistic" to its own political vision. The government tightened controlling measures such as budget auditing, fining, surveilling, or censoring materials of independent CSOs, especially the Kurdish CSOs. In some cases, the security forces arrested, or imprisoned, activists from Kurdish CSOs and political parties. The state control over Kurdish civil society became even stricter after the military coup attempt in July 2016. In its immediate aftermath, the AKP declared the state of emergency. The party governed the country by emergency decrees with the "force of law", until it has ended in July 2018. In November 2016, the Ministry of Interior banned 375 registered NGOs by a decree (No 677), 190 of them were Kurdish CSOs accused of having links to the PKK and its affiliates (Cetingulec, 2016). In this wave of closures, two Kurdish women's organizations I interviewed were shot down, and their assets were seized. Their activists continue to call for action via social media (Twitter, Facebook) and now work under the umbrella of other Kurdish women's CSOs. Under these authoritarian circumstances, organized Kurdish women continue to resist AKP's repression and patriarchal gender politics. Like all other women's groups, they stress the importance of building large coalitions among said groups

\footnotetext{
10 Personal communication with several feminist activists, October 2016, Bremen.
} 
because they claim that the government can target individual actions more easily. ${ }^{11}$ Forming a large coalition, for instance, helped to resist the aforementioned "rape law" proposal in 2016 and improved the capacities of organized women in pushing public institutions to enforce laws and regulations relating domestic violence. Despite the patriarchal governance of the AKP, the still operating Kurdish women's CSO I interviewed emphasizes on its webpage the importance of the sustainable cooperation with public institutions in combating violence against women (KAMER, 2018). Although interaction with the AKP government regarding policymaking on gender equality issues seems highly unlikely, cooperation with state actors on the local level and the lower level of bureaucracy is a viable possibility.

\subsection{Kemalist Women's CSOs}

Kemalist women-the defenders of the secularist and nationalist ideals of the Turkish state established by Mustafa Kemal (Atatürk)-were the first organized women's group in Turkey. Drawing upon the Kemalist state feminism that made women's equality a national policy, they primarily focused on strengthening gender equality in the legal framework but did not question the underlying patriarchal mechanisms in the public and the private sphere (Arat, 2008; Turam, 2008). Thanks to the rise of feminist activism in the 1980s, the Kemalist women's CSOs became more engaged in combating violence against women and pushing the governments for further legal reforms regarding women's rights (Marshall, 2009). Despite their distant attitude toward organized Kurdish and Islamist women, they became a constituent part of the women's movement. In the 1990s, organized Kemalist women were the only group that closely worked with state bodies and institutions responsible for women's issues (Aksoy, 2017).

\subsubsection{Engendering the Democratization before 2011}

In the AKP era, Kemalist women's CSOs, whose majority of members are legal experts on women's issues, primarily focused on combating violence against women. To this end, they developed the following strategies: 1) launching broad-based campaigns against domestic violence with the help of the secularist media, 2) raising public awareness through educational activities in public schools, and 3) lobbying parliamentarians to improve relevant laws. They were remarkably influential in negotiating with governmental institutions responsible for gender issues. In amending the Civil and Penal Codes and other legal reforms, organized Kemalist women lobbied and put pressure on policymakers sympathetic to gender issues (Marshall, 2009). Moreover, thanks to their links in the business world, Kemalist women's CSOs acquired financial or logistic support from wealthy businesswomen for the empowerment of women in education and the economic sector.

For a long time, Kemalist women's CSOs were advocates of the headscarf ban in public institutions. They saw the headscarf as a political symbol of religion that had no place in the secular public sphere in Turkey (Arat, 2008; Turam, 2008). In 2007, they were involved in mass rallies, protesting the AKP's attempt to lift the headscarf ban and the rise of Islamist politics in society and culture (Turam, 2008, p. 482). Organized Kemalist women claimed that Islamist politics threaten the secular way of life and, thus, women's freedoms. However, when the AKP government lifted the headscarf ban in public institutions in September 2013, there was no big reaction from Kemalist women's CSOs.

Kemalist women's CSOs argued that women's human rights are enshrined in national laws, but the progress and the enforcement are insufficient. In their public statements on flaws in gender laws and policies, they reminded the AKP of Turkey's obligation to eliminate discriminatory laws, as required by the CEDAW agreement and the Council of Europe's Istanbul Convention. As mentioned above, legal experts from Kemalist women's CSOs have assisted the state body responsible for gender issues (KSGM), in preparing the CEDAW country reports that present the legal changes aimed at reducing discrimination against women.

\subsubsection{In the Shadow of Authoritarianism after 2011}

Like all other women's groups, Kemalist women's CSOs point to the increasingly authoritarian and conservative approach of the AKP to gender issues. They also began to employ defensive strategies to resist backsliding in gender policies. Since the restructuring and renaming of the "Ministry of Women and Family" to "Ministry of Family and Social Policies" in December 2011, organized Kemalist women stress that the omission of the word "women" from the ministry's name means that women are not regarded as individuals, but only as "members of family". They have since been demanding a change in the name of the ministry. However, Erdoğan rejected this demand and stated: "We are a conservative party. For us, what is important is the family" (Belge, 2011). Organized Kemalist women have also been highly vocal on the low levels of women's participation in politics. Together with some feminist and Kurdish women's CSOs, they have been calling for the introduction of a minimum 30 percent gender quota system. ${ }^{12}$ However, the AKP vehemently rejects this idea. Also, Kemalist women's CSOs have addressed the low levels of women's participation in work force. They demand the introduction of institutional measures such as providing public childcare and elderly care services and guaranteeing equal opportunities in hiring processes. The AKP, however, introduced a new law to extend the paid maternity leave up to six months. The new

\footnotetext{
11 Personal communication, October 2016, Bremen.

12 Personal interview, November 2010, Istanbul.
} 
law additionally increased maternity allowance for each successive child, as a part of the AKP's pro-family policies (Kandiyoti, 2016, p. 113). Instead of establishing public child-care services, the government prefers to leave child-care issue to the private sector, which leads to discrimination against women from lower classes.

To resist the AKP's conservative gender discourse and politics, Kemalist women's CSOs stress the importance of the women's platforms to include various women's groups in processes of lobbying policymakers and negotiating with state institutions. They continue to use their links within the secularist media and in women's international networks. Yet, organized Kemalist women acknowledge that the religious-conservative political discourse of the AKP leadership and hostility towards organized women's demands make the struggle for gender equality increasingly difficult.

\section{Conclusions}

The gender and transition literature concentrated on one variant of the democratization process, namely transition to a full democracy, but failed to acknowledge and analyze the possibility of democratic reversal and the ensuing backsliding in gender politics. While gender and politics scholars newly began to analyze anti-gender movements and investigate dismantling of gender equality regimes in the context of de-democratization in Western democracies, I suggest that we need to look at empirical cases where anti-feminist actors have always contested gender equality and where the democratic pendulum has always been swinging between democratization and democratic reversal. In this regard, Turkey is a compelling case.

After a decade of democratic progress, Turkey now experiences democratic reversal, even an authoritarian revival, under AKP rule. Against this background, the AKP employs an ultra-conservative gender discourse and introduces pro-natalist and pro-family policies to cement ideals of traditional family roles (Acar \& Altunok, 2013; Kandiyoti, 2016). To this end, the AKP government, like any other government in authoritarian regimes, supports and finances pro-government women's organizations-under the guise of participatory democratic governance-and sidelines autonomous women's CSOs from policymaking processes (Kandiyoti, 2015). As this article showed, despite the authoritarian drift and anti-feminist discourse of the AKP, the autonomous women's CSOs have found alternative ways to mobilize and to resist AKP's conservative gender politics. While they employed pro-active strategies to initiate gender policy changes in democratization process before 2011, a shift to defensive strategies in the shadow of authoritarianism after 2011 has clearly occurred.

Similar to oppositional women's organizing in authoritarian regimes in Latin America and Eastern Europe (see Waylen, 2007), diverse groups of organized women in Turkey act as part of the broader opposition and in re- sponse to increasing repression under the AKP. Relying upon their long-years of experience in advocacy, lobbying, and monitoring, they employ three strategies to deal with the democratic reversal and backsliding in gender politics under AKP rule. First, organized women prefer to coalesce on the loosely organized large women's platforms, bringing a high number of CSOs from different groups together, to resist the AKP's gender-insensitive law proposals, as was the case in the "abortion" or "rape law" debate. The large women's platforms are more likely to capture and keep the public's attention and thereby to successfully apply pressure on policymakers to take necessary steps to stop the government introducing regressive gender policies. In contrast to pre-2011, these women's platforms are not issue-based and shortlived, rather they are utilized as a long-term strategy. These large platforms can, however, only prevail when organized women overcome the dominating ideological differentiations between themselves (Kurdish vs. Turkish; Islamist vs. Kemalist), which hampered their efficiency and influence until recently (Aksoy, 2017; Arat, 2008; Diner \& Toktaş, 2010; Kandiyoti, 2016). Second, the women's CSOs reach out to international women's networks (UN Women, CEDAW Committee) not only to acquire support for their gendered demands, but also to communicate with the AKP on equal terms. Since there is little or no dialogue between the AKP government and autonomous women's CSOs, they use the international platforms as a tool for communicating with the government. Third, all women's groups heavily use social media in attracting public attention to their gendered concerns. Social media has more potential to disturb the authority and is faster than print media in spreading the word. Thanks to combining the bottom-up and external pressure, women's rights groups succeed to respond to AKP's patriarchal backlash. While feminist, Kurdish, and Kemalist women's CSOs employ these strategies to oppose the patriarchal attacks, Islamist women's CSOs, as I observed, lost their visibility in the gendered struggle against AKP's authoritarianism, which needs a further analysis.

Drawing on my findings, the article maintains that the role of women CSOs is highly important to prevent regressive gender policies and to protect women's rights in the context of democratic reversal and authoritarian regimes. Women in formal political institutions can easily be sidelined and gender equality mechanisms be challenged by anti-democratic rulers. But thanks to their flexibility, women organized in the informal arena can find much faster alternative ways to circumvent the authority. The article argues that to more successfully prevent backsliding in gender politics, women's CSOs need to pursue three strategies: 1) create strong bottom-up pressure by using street protests and social media, 2) build large, heterogeneous (intersectional) and sustainable women's platforms to press gender-based demands, and 3) interact with state actors and the formal political arena. These strategies will help organized women to develop solutions to counteract anti-feminist sentiments and pol- 
itics in de-democratizing and authoritarian regimes on a global level. Sustainability and vigilance are the key terms for organized women in defying the patriarchy.

\section{Acknowledgments}

The author would like to thank to Mieke Verloo, David Paternotte, and two of the anonymous reviewers for their fruitful comments.

\section{Conflict of Interests}

The author declares no conflict of interests.

\section{References}

Acar, F., \& Altunok, G. (2013). The "politics of intimate" at the intersection of neo-liberalism and neo-conservatism in contemporary Turkey. Women's Studies International Forum, 41, 14-23.

Aksoy, H. A. (2015). Invigorating democracy in Turkey: The Agency of organized Islamist women. Politics \& Gender, 11(1), 146-170.

Aksoy, H. A. (2017). Engendering democracy in Turkey: Participation and inclusion of women's civil society organizations under AKP Rule. University of Tübingen, Tübingen, Germany. Retrieved from https:// publikationen.uni-tuebingen.de/xmlui/handle/10900 $/ 75204$

Altunok, G. (2016). Neo-conservatism, sovereign power and bio-power: Female subjectivity in contemporary Turkey. Research and Policy on Turkey, 1(2), 132-146.

Arat, Y. (2008). Contestation and collaboration: Women's struggles for empowerment in Turkey. In R. Kasaba (Ed.), The Cambridge history of TURKEY: Turkey in the modern world (Vol. 4, pp. 388-419). Cambridge: Cambridge University Press.

Aydin, S., \& Keyman, F. (2004). European integration and the transformation of Turkish democracy (EU-Turkey Working Papers No 2). Brussels: Centre for European Policy Studies.

Belge, B. (2011, June 8). Kadın bakanlığı kaldırıldı, kadın örgütleri öfkeli [Ministry for Women's Affairs abolished, women's organizations are angry]. Bianet. Retrieved from http://bianet.org/bianet/kadin/130 585-kadin-bakanligi-kaldirildi-kadin-orgutleri-ofkeli

Bora, A., \& Günal, A. (2007). 90larda Türkiye'de Feminizm [Feminism in the 1990s' Turkey] (2nd ed.). Istanbul: lletişim.

Cetingulec, T. (2016, November 21). State of emergency shuts down Turkey's NGOs. Al-Monitor Turkey Pulse. Retrieved from https://www.al-monitor.com/ pulse/turkey-pulse

Coşar, S., \& Onbaşi, F. G. (2008). Women's movement in Turkey at a crossroads: From women's rights advocacy to feminism. South European Society \& Politics, 13(3), 325-344.

Cupolo, D. (2016, November 21). Turkish rape law trig- gers protests. Deutsche Welle-English. Retrieved from http://www.dw.com/en/turkish-rape-lawtriggers-protests/a-36465426

Diamond, L. (1997). Is the third wave of democratization over? An empirical assessment (The Helen Kellogg Institute for International Studies Working Paper No 236). Notre Dame: University of Notre Dame.

Diamond, L., \& Plattner, M. (Eds.). (2015). Democracy in decline. Baltimore: Johns Hopkins University.

Diner, C., \& Toktaş, Ş. (2010). Waves of feminism in Turkey: Kemalist, Islamist and Kurdish women's movements in an era of globalization. Journal of Balkan and Near Eastern Studies, 12(1), 41-57.

Esen, B., \& Gumuscu, S. (2016). Rising competitive authoritarianism in Turkey. Third World Quarterly, 37(9), 1581-1606.

Freedom House. (2017). Freedom in the World 2017. Turkey Profile. Freedom House. Retrieved from https://freedomhouse.org/report/freedomworld/2017/turkey

Gökalp, D. (2010). A gendered analysis of violence, justice and citizenship: Kurdish women facing war and displacement in Turkey. Women's Studies International Forum, 33, 561-569.

Güneş-Ayata, A., \& Doğangün, G. (2017). Gender politics of the AKP: Restoration of a religio-conservative gender climate. Journal of Near Eastern and Balkan Studies. doi:10.1080/19448953.2017.1328887

KAMER. (2018, April 27). KAMER Vakfı 2014-2017 Yıllarında Neler Yaptı [What did the KAMER Foundation do between 2014-2017]? KAMER. Retrieved from http://www.kamer.org.tr/icerik_detay.php?id=384

Kandiyoti, D. (2015). The gender wars in Turkey: A litmus test of democracy? Open Democracy Online. Retrieved from https://www.opendemocracy.net/ 5050/deniz-kandiyoti/gender-wars-in-turkey-litmustest-of-democracy

Kandiyoti, D. (2016). Locating the politics of gender: Patriarchy, neo-liberal governance and violence in Turkey. Research and Policy on Turkey, 1(2), 103-118.

Krook, M. L., \& Messing-Mathie, A. (2013). Gender quotas and comparative politics: Past, present, and future research agendas. Politics \& Gender, 9, 299-328.

Letsch, C. (2013, February 1). Turkish law will make legal abortion impossible, say campaigners. The Guardian. Retrieved from https://www.theguardian.com/ world/2013/feb/01/turkish-law-abortion-impossible

Levitsky, S., \& Way, L. (2002). The rise of competitive authoritarianism. Journal of Democracy, 13(2), 51-65.

Linz, J., \& Stepan, A. (1997). Toward consolidated democracies. In L. Diamond, M. F. Plattner, Y. Chu, \& H. Tien (Eds.), Consolidating the third wave democracies: Themes and perspectives (Vol. 1, pp. 14-33). Baltimore and London: The Johns Hopkins University Press.

Marshall, G. A. (2009). Authenticating gender policies through sustained-pressure: The strategy behind the success of Turkish feminists. Social Politics: Interna- 
tional Studies in Gender, State and Society, 16(3), 358-378.

Müftüler-Baç, M., \& Keyman, F. E. (2012). Turkey under the AKP: The era of dominant-party politics. Journal of Democracy, 23(1), 8599.

Ottoway, M. (2000). Democratic reversals. Carnegie Endowment for International Peace. Retrieved from http://carnegieendowment.org/2000/07/01/demo cratic-reversals-pub-763

Ozcetin, H. (2009). "Breaking the silence": The religious Muslim women's movement in Turkey. Journal of International Women's Studies, 11(1), 106-119.

Öniş, Z. (2013). Sharing power: Turkey's democratization challenge in the age of the AKP hegemony. Insight Turkey, 15(2), 103-122.

The Guardian. (2014, November 24). Recep Tayyip Erdoğan: "Women not equal to men". The Guardian. Retrieved from https://www.theguardian.com/ world/2014/nov/24/turkeys-president-recep-tayyiperdogan-women-not-equal-men

The Guardian. (2016, June 6). Turkish president says childless women are "deficient, incomplete". The Guardian. Retrieved from https://www.theguardian. com/world/2016/jun/06/turkish-president-erdogan- childless-women-deficient-incomplete

Turam, B. (2008). Turkish women divided by politics: Secularist activism versus pious non-resistance. International Feminist Journal of Politics, 10(4), 475-494.

Tremblay, P. (2016, November 23). Turkey backpedals on statutory rape proposal. Al-Monitor Turkey Pulse. Retrieved from https://www.al-monitor.com/ pulse/turkey-pulse

Verloo, M. (2007). Multiple meanings of gender equality: A critical frame analysis of gender policies in Europe. Budapest: CEU Press.

Walby, S. (2011). The future of feminism. Cambridge: Polity Press.

Waylen, G. (2007). Engendering transitions: Women's mobilization, institutions, and gender outcomes. Oxford and New York: Oxford University Press.

Waylen, G. (2015). Engendering the "crisis of democracy": Institutions, representation and participation. Government and Opposition, 50(3), 495-521.

Yüncüler, Z. (2014, February 19). Yasa yok ama kürtaj yasak [There is no law, but abortion is forbidden]. Milliyet. Retrieved from http://www.milliyet.com.tr/ yasa-yok-ama-kurtaj-yasak/gundem/detay/1838845 /default.htm

\section{About the Author}

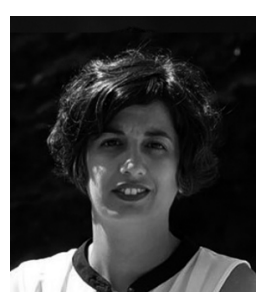

Hürcan Aslı Aksoy is an Assistant Professor at the Chair of Middle East Politics and Society of the University of Erlangen-Nürnberg (Germany). Aksoy's areas of research are democratization and autocratization; gender and politics; civil society; organized women and state; state-society relations in the Middle East from a comparative perspective. Recent publications include the bi-lingual edited volume Patriarchat im Wandel: Frauen und Politik in der Türkei (2018). Her current research is on the prospects of gender politics in illiberal democracies and autocracies. 